\title{
Hubungan Graviditas dengan Kejadian Preeklamsia pada Ibu Bersalin Kabupaten Bulukumba Tahun 2017
}

\section{The Relationship between Gravidity and Preeclampsia in Mother of Labor Bulukumba of Regency in 2017}

\author{
Risnawati*1 $^{1}$, Ely Kurniati ${ }^{2}$ \\ ${ }^{1,2}$ Program Studi Diploma III Kebidanan, STIKes Panrita Husada, Bulukumba, Sulawesi Selatan, Indonesia \\ *Korespondensi Penulis: rhiesnaqueen@gmail.com
}

\begin{abstract}
Abstrak
Preeklampsia adalah terjadinya hipertensi setelah usia kehamilan 20 minggu disertai dengan protein urine. Penelitian ini bertujuan untuk mengetahui hubungan graviditas dengan kejadian preeklamsia di Kabupaten Bulukumba Tahun 2017. Desain penelitian yang digunakan adalah historical kohort. Populasi dan sampel dalam penelitian ini adalah pasien yang mengalami preeklamsia 73 dan yang tidak mengalami preeklamsia 259 orang di 20 wilayah kerja puskesmas di lingkup Kabupaten Bulukumba dengan menggunakan teknik cluster sampling, alat ukur yang digunakan adalah lembar observasi. Analisa data dalam penelitian ini menggunakan uji statistik Chi-square. Berdasarkan uji statistic yang diperoleh hasil $P=0,000$. Kesimpulan dari penelitian ini adalah ada Hubungan Graviditas dengan Kejadian Preeklamsia Pada Ibu Bersalin di Tingkat Kabupaten Bulukumba tahun 2017.
\end{abstract}

Kata Kunci: graviditas, preeklamsia

\begin{abstract}
Preeclampsia is hypertension after 20 weeks' gestation is collected with urine protein. This study aims to determine the relationship of gravidity with the incidence of preeclampsia in Bulukumba Regency in 2017. The research design used was a historical cohort. The population and sample in this study were patients who experienced an increase in preeclampsia 73 and who did not increase preeclampsia by 259 people in 20 puskesmas working areas in Bulukumba Regency and using cluster sampling techniques, the measuring tool used was gluing. Data analysis in this study using Chi-square statistical test. Based on the statistical test results obtained $P=0,000$. The conclusion of this study is that there is a Gravidity Relationship with the incidence of Preeclampsia in Maternity at the Level of Bulukumba District in 2017.
\end{abstract}

Keywords: gravidity, preeclampsia 


\section{PENDAHULUAN}

Preeklamsia adalah salah satu gangguan kesehatan yang menyerang ibu hamil, bersalin, dan nifas, ditandai dengan meningkatnya tekanan darah dan protein urin.Penyakit ini cukup berbahaya bagi ibu hamil, bersalin, serta nifas. Ibu hamil yang terserang preeklamsia akan mengalami penyempitan pembuluh darah sehingga akan menekan fungsi hati, ginjal, otak, dan beberapa organ vital lainnya. Preeklamsia terjadi pada umur kehamilan diatas 20 minggu, paling banyak terlihat pada umur kehamilan 37 minggu, tatapi dapat juga timbul kapan saja pada pertengahan kehamilan bahkan menjelang persalinan (Purwoastuti \& Elisabeth, 2015).

Dampak akibat preeklamsia bisa berdampak pada ibu dan janin, tergantung pada derajat preeklamsia yang dialami. Namun yang termasuk komplikasi antara lain : dapat menyebabkan penderita mengalami Stroke, eklampsia, solusio plasenta, perdarahan subkapsula hepar, kelainan pembekuan darah (DIC), Sindrom HELLP, gagal jantung hingga syok dan kematian, Hipoksia janin, asfiksia neonatorum, premature, gagal ginjal, kebutaan, kejang, hipertensi permanen, distress fetal, infarkplasenta, abruption plasenta, kematian janin dalam uterus (Purwoastuti \& Elisabeth, 2015).

Data dari kementerian kesehatan republik indonesia tahun 2016 menerangkan bahwa Kematian ibu di Indonesia masih didominasi oleh tiga penyebab utama kematian yaitu perdarahan, hipertensi dalam kehamilan meliputi(preeklamsia-eklamsia) dan infeksi. Namun proporsinya telah berubah, dimana perdarahan dan infeksi cenderung mengalami penurunan sedangkan Hipertensi Dalam Kehamilan meliputi preeklamsia dan eklamsia proporsinya semakin meningkat. yaitu pada tahun 2010 telah terjadi kematian ibu (21,5\%), 2011 sebanyak (24,7\%), 2012 sebanyak (26,9\%) dan pada tahun 2013 meningkat menjadi $(27,1 \%)$.

Salah satu faktor penyebab preeklamsia/eklamsia adalah graviditas. Graviditas yang paling berpengaruh adalah primigravida muda dibandingkan dengan multigravida. Hal ini diduga karena pada kehamilan pertama cenderung terjadi kegagalan pembentukan blocking antibodies terhadap antigen plasenta sehingga timbul respon imun yang tidak menguntungkan terhadap kemampuan pembentukan jaringan plasenta, dimana kejadian preeklamsia lebih umum terjadi pada primigravida, sedangkan pada multigravida berhubungan dengan penyakit hipertensi kronis, diabetes mellitus dan penyakit ginjal. Pada primigravida atau ibu yang pertama kali hamil sering mengalami stress dalam persalinan sehingga dapat terjadi hipertensi dalam kehamilan atau yang biasa disebut preeklamsia/eklamsia. 
Adapun upaya yang harus dilakukan oleh pemerintah untuk menurunkan angka kematian yang disebabkan oleh preeklamsia yaitu promosi kesehatan tentang pentingnya kunjungan antenatal pada ibu hamil agar bisa terdeteksi sedini mungkin ibu hamil yang mengalami preeklamsia karena ibu hamil masih kurang melakukan kunjungan antenatal, kemudian pentingnnya KBPP pada saat setelah bersalin untuk memulihkan kembali sistem organ dalam tubuh paling tidak menunda selama dua tahun hamil lagi karena dapat membantu menurunkan angka kematian pada ibu, bayi, dan balita.

\section{METODE PENELITIAN}

Jenis penelitian yang digunakan adalah penelitian analitik yang merupakan pencarian fakta dengan interpretasi yang tepat.studi analitik dengan desain historikal kohort, adalah penelitian yang menggunakan data yang telah terjadi sebelum dimulainya penelitian, sehingga variabel-variabel tersebut diukur melalui catatan historis. Populasi adalah wilayah generalisasi yang terdiri atas: obyek/subyek yang mempunyai kualitas dan karakteristik tertentu yang ditetapkan oleh peneliti untuk dipelajari dan kemudian ditarik kesimpulannya (Sugiyono, 2011 dikutip dalam Susila dan Suyanto, 2014). Populasi dalam penelitian ini adalah ibu bersalin yang berada di wilayah kerja 20 Puskesmas di lingkup Kabupaten Bulukumba Tahun 2017.

Pengambilan sampel yang digunakan dalam penelitian ini menggunakan teknik Cluster Sampling yakni teknik pengambilan sampel bila objek yang akan diteliti atau sumber data yang sangat luas, maka pengambilan sampelnya berdasarkan daerah populasi yang telah ditetapkan (Sugiyono, 2012). Diperoleh jumlah sampel dalam penelitian ini adalah 332 orang ibu bersalin yang ada di Kabupaten Bulukumba tahun 2017. Alat yang digunakan untuk mengumpulkan data dalam penelitian ini adalah daftar lembar observasi dengan menggunakan data sekunder yang diambil dari rekam medik setiap Puskesmas di lingkup Kabupaten Bulukumba.

Data dianalisis berdasarkan skala ukur dan tujuan penelitian dengan menggunakan perangkat lunak program komputerisasi. Data analisis secara : (1) Analisa Univariat, Analisa dilakukan untuk melihat distribusi frekuensinya. (2) Analisa Bivariat, Analisa yang dilakukan untuk menganalisis hubungan dua variabel dengan uji yang digunakan chi-squaredengan diharapkan dengan derajat kemaknaan 0,05. 


\section{HASIL DAN PEMBAHASAN}

Berdasarkan tabel 5.3 menunjukkan bahwa responden yang memilki resiko tinggi 53 $(41,1 \%)$ lebih besar mengalami PE dibandingkan dengan beresiko rendah 20 orang $(9,9 \%)$ sehingga secara presentase dapat disimpulkan bahwa ada hubungan anatara graviditas dengan kejadian preeklamsia. Hasil uji statistic menunjukkan bahwa nilai $\mathrm{P}<0,05$, hal ini terbukti bahwa graviditas berhubungan secara bermakna dengan kejadian preeklamsia . dari analisis keeratan hubungan menunjukkan nilai Odd Ratio (OR) 6,381 yang berarti bahwa responden yang beresiko tinggi mempunyai peluang 6,381 kali mengalami PE dibandingkan dengan beresiko rendah.

Tabel 1. Distribusi Hubungan Graviditas Dengan Kejadian Preeklamsia Ibu Bersalin di 20 Wilayah Kerja Puskesmas Kabupaten Bulukumba Tahun 2017

\begin{tabular}{|c|c|c|c|c|c|c|c|c|}
\hline \multirow{3}{*}{ Graviditas } & \multicolumn{4}{|c|}{ Kejadian Preeklampsia } & \multirow{2}{*}{\multicolumn{2}{|c|}{ Total }} & \multirow{3}{*}{\multicolumn{2}{|c|}{$\begin{array}{c}\text { Nilai } \\
\mathbf{p}\end{array}$}} \\
\hline & \multicolumn{2}{|c|}{$\begin{array}{c}\text { Tidak } \\
\text { Preeklampsia }\end{array}$} & \multicolumn{2}{|c|}{ Preeklampsia } & & & & \\
\hline & f & $\%$ & $\mathbf{f}$ & $\%$ & $\mathbf{f}$ & $\%$ & & \\
\hline Beresiko rendah & 183 & $(90,1)$ & 20 & $(9,9)$ & 203 & $(100,0)$ & 0,00 & 6,381 \\
\hline Beresiko tinggi & 76 & $(58,9)$ & 53 & $(41,1)$ & 129 & $(100,0)$ & & \\
\hline Total & 259 & $(78,0)$ & 73 & $(22,0)$ & 332 & $(100,0)$ & & \\
\hline
\end{tabular}

Nilai $p=0,00$ lebih kecil dari nialai $\alpha 0,05$

Berdasarkan hasil analisis menggunakan uji statistic Chi-square diperoleh nilai Asymp. Sig sebesar 0,000 dengan 0 cell yang memiliki nilai expected count lebih dari 5 sehingga diperoleh nilai $\mathrm{P}=0,000$, Nilai signifikan 0,000 tersebut menunjukkan lebih kecil dari $5 \%$ yaitu 0,05 , maka dapat dinyatakan terdapat hubungan graviditas dengan kejadian preekalmsia di tingkat kabupaten Bulukumba Tahun 2017.

Hasil yang diperoleh dalam analisis menggunakan uji statistic Chi square yaitu nilai $\mathrm{P}<0,005$. Berdasarkan hasil uji SPSS yang telah diinterpretasi, ternyata tidak terdapat cell yang memiliki nilai expected count kurang dari 5. Berdasarkan hasil tersebut, uji Chi square yang didapatkan dengan tabel $2 \times 2$ dan diperoleh $\mathrm{P}<0,005$.

Hasil akhir tersebut dapat disimpulkan bahwa Ha diterima dan Ho di tolak yang berarrti ada hubungan Graviditas Dengan Kejadian Preeeklamsia di Tingkat Kabupaten Bulukumba.

Hal ini sejalan dengan teori Preeklamsia didentifikasi melalui adanya hipertensi, dan proteinuria pada seorang perempuan hamil yang tadinya normatensif. Penyakit ini timbul sesudah minggu ke 20 atau segera setelah persalinan dan paling sering terjadi pada 
primigravida yang muda faktor yang mempengaruhi preeklamsia dan eklamsia lebih tinggi frekuensinya pada primigravida dibandingkan dengan multigravida, terutama pada primigravida dengan usia muda. Hal tersebut dikarenakan wanita dengan preeklamsia dan eklamsia dapat mengalami kelainan aktivitas imun dan hal ini dapat menghambat invasi trovoblas pada pembuluh darah ibu.(martaaadisoebrata, dkk 2013).

Hal ini didukung dengan penelitian Seperti yang dikemukakan oleh Nur Djanah (2014) menunjukkan angka kejadian preeeklamsia lebih banyak pada ibu bersalin dengan paritas risti ( 1 dan >3) yaitu sebanyak 75,51\% dengan analis Chi square didapatkan $\mathrm{P}$ value $<0,005$, OR 3.87, CI 2.30-6.61 dengan analisis regresi logistic multivariate didapatkan koefisiensi regresi paritas 1.5408 .

Adapun asumsi peneliti hal ini disebabkan pada ibu yang pernah melahirkan 2-4 kali terjadi penurunan insidensi.Hipertensi karena kehamilan lebih sering pada primigravida, terjadi akibat implantasi sehingga timbul iskemia plasenta yang diikuti sindrom inflamasi.Secara imunologik pada kehamilan pertama pembentukan blocking antibodies terhadap antigen plasenta tidak sempurna sehingga timbul respon imun tidak menguntungkan terhadap kemampuan pembentukan jaringan plasenta menurun dan mengakibatkan iskemia uterus, merangsang pelepasan bahan tropoblastik yaitu akibat hiperoksidase lemak dan pelepasan renin uterus.

Bahan troboplastik menyebabkan terjadinya endhotheilosis menyebabkan pelepasan tomboksan dan aktivasi agregasi Itrombosit deposisi fibrin akan menyebabkan koagulasi intravascular yang menyebabkan perfusi darah menurun dan konsumtif koagulapati.

Konsumtif koagulapati mengakibatkan trombosit dan faktor pembekuan darah menurun dan menyebabkan gangguan faal hemostatis. Renin uterus yang di keluarkan akan mengalir bersama darah sampai organ hati dan bersama-sama angiotensinogen menjadi angiotensin I dan selanjutnya menjadi angiotensin II. Angiotensin II bersama tromboksan akan menyebabkan terjadinya vasopasme. Vasopasme menyebabkan lumen anteriol menyempit.

Lumen anteriol yang menyempit menyebabkan lumen hanya dapat dilewati oleh satu sel darah merah. Tekanan perifer akan meningkat agar oksigen mencukupi kebutuhan sehingga menyebabkan terjadinya hipertensi dan pembentukan "blocking antibodies" terhadap antigen yang tidak sempurna selain itu pada kehamilan primigravida terjadi pembentukan "Human Leucocyte Antigen Protein (HLA)" yang berperan penting dalam 
modulasi respon immune, sehingga ibu menolak hasil konsepsi (plasenta) atau terjadi intoleransi ibu terhadap plasenta sehingga terjadi preeklamsia.

\section{KESIMPULAN}

Berdasarkan hasil penelitian diatas maka disimpulkan bahwa ada hubungan graviditas dengan kejadian preeklamsia pada ibu bersalin di Kabupaten Bulukumba Tahun 2017.

\section{SARAN}

1. Bagi tenaga kesehata khususnya bidan agar bisa memberikan pendidikan kesehatan tentang pentingnya menjaga kesehatan selama masa kehamilan.

2. Untuk peneliti selanjutnya dengan kasus yang sama dapat menambahkan variabel lain dalam penelitiannya, seperti status gizi, aktivitas fisik, genetic dengan menggunakan longitudinal study untuk kepentingan ilmu yang berkembang selanjutnya.

\section{DAFTAR PUSTAKA}

Alifariki, L. O. (2015). Analisis faktorDeteminan Proksi Kejadian Hipertensi Di Poliklinik Interna BLUD RSU Provinsi Sulawesi Tenggara. Medula , 221.

Amu, D. A. (2015). Faktor-faktor yang berhubungan dengan hipertensi di Wilayah Perkotaan dan Pedesaan Indonesia Tahun 2013. 103.

Efendi, F., \& Makhfudli. (2009). Keperawatan Kesehatan Komunitas: Teori dan Praktek dalam Keperawatan. Jakarta: Salemba Medika.

Indonesia, K. K. (2013). Buku Saku Pelayanan Kesehatan Ibu di Fasilitas Kesehatan Dasar dan Rujukan . Indonesia: AIPKIND .

Iriyanti, B., Halida, E. M., Duhita, F., Prabandari, F., Yulita, N., Yulianti, N., et al. (2015). Asuhan Kehamilan Berbasis Bukti. Jakarta: Sagung Setoo.

Jusniar Rusliafa, R. A. (2014). komparatif kejadian hipetensi pada wilayah pesisir pantai dan pegunungan di kota kendari tahun 2014. 6.

Kementeriankesehatan. (2015, desember 1). kesehatan dalam kerangka sustainable development goals (SDG's). kesehatan dalam kerangka sustainable development goals $(S D G$ 's) .

Manuaba, I. A. (2012). ilmu kebidanan, penyakit kandungan, dan KB untuk pendidikan bidan edisi 2. jakarta : EGC.

Maryunani, A. (2016). Asuhan Kegawatdaruratan dalam Kebidanan Edisi Kedua. Jakarta: Trans Info Medika.

Mochamad, R. (2013). Buku Ajar Biostatistik: Aplikasi Pada Penelitian Kesehatan . Jakarta: EGC.

Nugroho, d. T. (2012). Patologi Kebidanan. Yogyakarta: Nuha Medika. 
Nur, D. A. (2015). Faktor-faktor yang berhubungan dengan hipertensi diwilayah perkotaan dan pedesaan Indonesia tahun 2013. 3.

Prawirohardjo, S. (2014). ilmu bkebidanan. jakarta: PT Bina Pustaka Sarwono Prawirohardjo.

Saputra, O., \& Anam, K. (2016). Gaya hidup sebagai faktor resiko Hipertensi pada masyarakat pesisir pantai. Majority, 122.

Sirait, A. M. (2012). Prevalensi Hipertensi Pada Kehamilan Di Indonesia dan berbagai Faktor Yang berhubungan (Riset Kesehatan Dasar 2007). Buletin Penelitian Sistem Kesehatan , 108.

Sulistyawati, A. (2013). Asuhan Kebidanan Pada Masa Kehamilan. Jakarta: Salemba Medika.

Vasra, E. (2014). Asuhan Kebidanan Komunitas Konsep Dan Praktik. jakarta: EGC. 